\title{
Impact of FDI in Agriculture Sector in India: Opportunities and Challenges
}

\author{
G. Nedumaran, M. Manida
}

\begin{abstract}
Foreign Direct Investment has a vital errand to do in the rustic part for the Indian financial system. FDI is empowered in the cultivating section to improve the idea of yields. In the Indian Economy the FDI inflows to the cultivating portion since 2010 - 2018 there is an important perfection in the Agriculture section. Agriculture is said to be the establishment of the nation and it encompasses of $65 \%$ of the Indian people. Along these lines, the methodologies are limited in gathering to the agriculture influences a people. In order to forgo the poverty, government has upheld the FDI in Agricultural part and it is most acclaimed way to deal with discard the dejection and longing for. There is an emergency in agrarian part because of the colossal advances and advances which are paid by the banks to the ranchers. The ongoing patterns in the horticultural part have delineated a deceleration in the agrarian development. FDI in Agricultural Sector is one of the copious walks in improving bothers of Indian Farmers. For propelling cultivating improvement, reducing poverty and hunger, and progressing environmental supportability, country theory is crucial. FDI enthusiasm for agriculture requires a logically point by point ask about. Both positive and negative impact should be eagerly examination, with respect to Indian economy. In order to grow the lifestyle for the people and to engage those to use for sound and reflex improvements it is pivotal principal that, capital course of action ought to occur at a higher rate. This paper attempts to consider the impact of FDI in India expressly in green part and to examine the likelihood and confusions looked by the fragment in pulling in the black out budgetary masters adjacent to the various exercises taken by the administrationBased on the results and findings, suitable suggestions and conclusions will be made for the further research.
\end{abstract}

Keywords : FDI, Globalization, Environmental Sustainability, Technological Innovation, Capital Formation.

\section{INTRODUCTION}

$100 \%$ FDI is moreover permitted in tea part. Other than the previously mentioned, FDI isn't allowed in some other country part/development. Game plan for FDI in Multi-Brand Retail Trading (MBRT) gives that in any occasion half of the essential tranche of US \$ 100 million will be returned assets into end establishment which fuses advancement of warehousing and cold stores. The provincial region in India is the rule wellspring of work for more than 70

Revised Manuscript Received on October 15, 2019.

* Correspondence Author

Dr. G. NEDUMARAN, Associate Professor, Department of Commerce, Alagappa University, Karaikudi.

Mr. M. MANIDA, Full - Time Scholar, Department of Commerce, Alagappa University, Karaikudi percent of the rural masses. Moreover half of the nuclear families in the provincial masses give some sign of poverty (Singh and Walis 2015). In this circumstance if the essential purpose of the Indian government is budgetary improvement and destitution decline, by then the need should be the advancement of the cultivating division. One of the huge changes in the agribusiness region starting late is the inflow of remote direct adventure. Regardless of the way that a huge bit of the locales in agribusiness division is so far closed for the outside endeavor. There has been tremendous addition in outside enthusiasm for a couple of parts. In India, cultivating accept a pivotal position in describing the supportability and advancement of the country and that is the reason it has reliably been the undeniable dispersion. India is the second greatest producer of wheat and rice, many dry natural items, certain agribusiness based material unrefined materials, roots and tuber yields, beats, etc are made by Indian cultivation division. India positions second or third position for making of these things (Sonawan, 2017). Agribusiness is the fundamental wellspring of business for around 58 percent of India's people. Gross Value Added by agribusiness, officer supervision and scheming is surveyed at Rs 18.53 trillion (US\$ 271.00 billion) in FY18.

The Indian sustenance industry is adjusted for colossal advancement, extending its promise to world sustenance trade every year on account of its enormous potential for worth development, particularly inside the sustenance dealing with industry. The Indian sustenance and essential nourishment thing business sector is the world's sixth greatest, with retail contributing 70 percent of the arrangements. The Indian sustenance planning industry speaks to 32 percent of the country's hard and fast sustenance exhibit, maybe the greatest business in India and is situated fifth with respect to creation, usage, convey and foreseen advancement. It contributes around 8.80 and 8.39 percent of Gross Value Added (GVA) in Manufacturing and Agriculture independently, 13 percent of India's charges and six percent of hard and fast current endeavor. 


\section{REVIEW OF LITERATURE}

Sonawane Shantaram Tarachand (2017), in his paper entitled "A study on FDI in agriculture sector in India" concluded that Union govt. should frame policies in this regard with state govt. which should be free from beaurocratical process; out of use laws \& traditions; corruption and non-transparency then this will lead to fair production in economy. Proper attention should be given to all allied activities if we want faster, sustainable and more inclusive growth in agriculture.

Sumit Saini, in their article entitled "Impact of FDI on Agriculture Sector in India: An Analytical Approach" Observed that Floriculture, Horticulture, Apiculture and Cultivation of Vegetables \& Mushrooms under controlled conditions and Development and Production of seeds and planting material; and also in Services related to agro and allied sectors.100\% FDI is also permitted in plantation sector namely Tea plantations, Coffee plantations, Rubber plantations, Cardamom plantations, Palm Oil plantations and Olive oil tree plantations through automatic route. 100 percent FDI is allowed in "Single Brand product retail trading". 51\% FDI is permitted in "multi brand retail trading" with condition that fresh agricultural produce, including fruits, vegetables, flowers grains, pulses may be unbranded.

Sandeep Kumar, Kavita, in their paper entitled "Foreign Direct Investment in Indian Agricultural Sector: Opportunities and Challenges States" highlighted an effort of poverty reduction and economic development must address the problems being faced by the agricultural sector and turn the challenges into economic opportunities for the poor population in rural India. India being a participant to World Trade Organization's General Agreement on Trade in Services, which include wholesale and retailing services, had to open up the retail trade sector to foreign investment.

\section{OBJECTIVES OF THE STUDY}

- To study the impact of FDI in agriculture sector in opportunities and challenges.

- To study the benefits of the study.

- To Analysis the FDI in agriculture sector in India

\section{IMPACT OF FDI IN AGRICULTURE SECTOR IN INDIA: OPPORTUNITIES AND CHALLENGES}

The positive results of the approach are as per the following:

- Allowing isolated interest in horticultural retailing is probably going to guarantee sufficient progression of capital into provincial economy in a way liable to advance the welfare of all areas of society, especially ranchers and shoppers.
It will achieve upgrades in rancher pay and rural development and help with bringing down shopper value swelling.

- Because of absence of satisfactory foundation offices and absence of legitimate storeroom ranchers are compelled to sell their items at extremely low value which now and then can't take care of their expense of creation. It is expected that now rancher could be sell their all maker.

- Since the inflow of FDI in retail area will undoubtedly draw up the quality measures and cost intensity of Indian ranchers. It, consequently, appears that FDI in rural retailing has the capability of supporting agrarian development.

- This is relied upon to support the nation's household fabricating industry that outside retail organizations must be source in any event 30 percent of the products from little and miniaturized scale businesses.

- The base venture point of confinement has been set at US\$ 100 million for remote organizations, out of which in any event 50 percent must be utilized to improve transportation, dissemination, stockpiling, and bundling offices, and create homestead partnered foundation.

- Due the FDI creativity, the idea of the broker, which has ruled ranchers in India for quite a long time, can be killed and ranchers would now be able to get the full advantage of their produce.

- Outside organizations are relied upon to make some helpful strides for the production of store network. Passage of remote players, stockpiling and refrigeration framework will improve altogether.

- Openings for work in parts, for example, transportation, bundling, horticulture handling and such like are required to thrive. Concurring the Government of India, FDI in retail division is able to do producing roughly 4 million direct occupations and around 5 to 6 million aberrant employments inside a range of 10 years.

\section{IMPACT OF FDI IN AGRICULTURE SECTOR IN INDIA: CHALLENGES}

The FDI arrangement likewise accompanies a lot of impediments of the approach are:

1. Little retailers and proprietors of Pop and Mom stores may endure, as the enormous retailers like WalMart and Tesco are probably going to ease out these little and smaller scale level retailers.

2. There may be work misfortunes in the assembling portion. Despite the fact that the administration has topped the sourcing of wares from the local market at 30 percent, the remainder of the 70 
percent can be purchased from the remote markets.

3. The Indian retailers probably won't most likely adapt up to the expanding rivalry from the outside retailers who are solid and steady with better foundation and the executives' methodology. Gradually this might prompt the replacement of the Indian retailers to an impressive degree.

4. As the outside brands will be accessible at a greater rate, the customer's tendency towards universal brands may influence the nation's in-house brands.

5. As indicated by the non-government religion, FDI will deplete out a lot of profits to isolated nations which may cause negative effect on India's general economy.

6. Presently Wall bazaar is the single purchaser and play as a monopolist and it will be power to rancher to lessen the cost of their produce.

7. It is said that FDI may give work openings, however it is contended that it can't give business chances to semi-uneducated individuals. This contention acquires significance since in India; enormous quantities of semi-uneducated individuals are available.

8. Despite the fact that Government has foreordained that 30 percent obtainment ought to be from Indian sources, this may get weakened throughout the years. The rest of the 70 percent acquisition from less expensive nations will make the individuals keep running towards that stuff and the 30 percent supply from Indian little ventures will have their own demise, incapable to contend with low value Chinese products.

\section{BENEFITS OF FDI IN AGRICULTURE SECTOR}

1. The concept of contract farming would come of age in India. As a concept, Contract farming ensures execution of concepts like Agro Credit, Insurance, development in agriculture.

2. Robust request: a huge populace and rising urban and rustic pay are driving the interest, while outer interest is driving the expansion in horticulture specialists from India.

3. Attractive Opportunities: interest for farming information sources and united administrations like warehousing and cold stockpiling in expanding in India at a quick pace.

4. Policy Support: Schemes like Paramparagat Kvishikas Yojana helps in creating natural bunches and make accessible substance free contributions to ranchers.

5. Government of India is likewise pointing the twofold rancher pay by 2022 .

6. Competitive Advantage: High extents of agrarian land, various agro-climatic conditions support development of various harvests.

7. Small farmers and agricultural workers would be additional enthused to team up with cooperatives which would allow computerization of land and multiple cropping which was not likely for practical complications.

8. Indian Food Processing Industry can come of age. As proposed in the 12th FYP, food processing has been given particular opportunity which would allow farmers to get involved towards food processing industry.

Table 1:STATEMENT ON SECTOR-WISE FDI EQUITY INFLOWS from APRIL 2000 TO MARCH 2019

\begin{tabular}{|l|c|c|c|c|}
\hline $\begin{array}{l}\text { S. } \\
\text { No }\end{array}$ & Sector & $\begin{array}{c}\text { Amount } \\
\text { of FDI } \\
\text { Inflows } \\
\text { (In Rs } \\
\text { Crore) }\end{array}$ & $\begin{array}{c}\text { \%age of } \\
\text { Total } \\
\text { Inflows }\end{array}$ & $\begin{array}{c}\text { Sector wise } \\
\text { Percentage }\end{array}$ \\
\hline 1 & $\begin{array}{c}\text { Agriculture } \\
\text { Sectors }\end{array}$ & $\begin{array}{c}11126.2 \\
8\end{array}$ & $\begin{array}{c}11126.2 \\
8\end{array}$ & $46.33 \%$ \\
\hline 2 & Sugar & 1276.72 & 12403 & $5.31 \%$ \\
\hline 3 & $\begin{array}{c}\text { Vegetable } \\
\text { Oils and } \\
\text { Vanaspati }\end{array}$ & 5253.48 & $\begin{array}{c}17656.4 \\
8\end{array}$ & $21.88 \%$ \\
\hline 4 & Fertilizers & 3847.09 & 21503.5 & $16.02 \%$ \\
\hline 5 & $\begin{array}{c}\text { Agricultural } \\
\text { machinery }\end{array}$ & 2512.63 & 24016.2 & $15.77 \%$ \\
\hline & TOTAL & $\mathbf{2 4 0 1 6 . 2}$ & & \\
\hline
\end{tabular}

Source: Ministry of Agriculture and Farmer welfare

The Table 1 shows that highest amount of Foreign Direct Investment Inflows in the Agriculture Sectors. Every year increased the amount of FDI inflows the Agriculture Sectors.

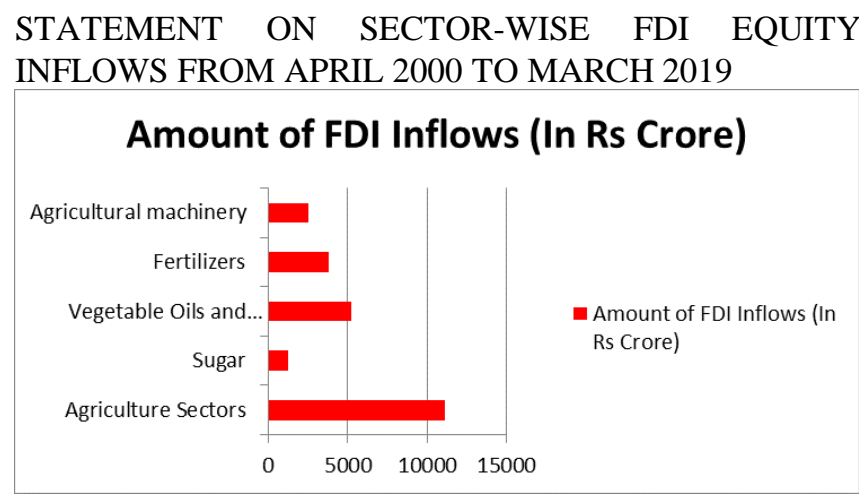

Figure 1: Column Diagram shows the statement on sector-wise FDI equity inflows from April 2000 to March 2019 (Table No 1)

Table 2:DPIIT's - FINANCIAL YEAR-WISE FDI EQUITY INFLOWS

\begin{tabular}{|c|c|c|c|}
\hline S. No & Financial Year & $\begin{array}{c}\text { Amount of } \\
\text { FDI } \\
\text { Inflows } \\
\text { In Rs } \\
\text { Crores }\end{array}$ & \\
\hline 1. & $2010-11$ & 97,320 & 97,320 \\
\hline 2. & $2011-12$ & $1,65,146$ & $2,62,466$ \\
\hline 3. & $2012-13$ & $1,21,907$ & 384373 \\
\hline 4. & $2013-14$ & $1,47,518$ & 531891 \\
\hline 5. & $2014-15$ & $1,81,682$ & 713573 \\
\hline 6. & $2015-16$ & $2,62,322$ & 975895 \\
\hline
\end{tabular}




\begin{tabular}{|c|c|c|c|}
\hline 7. & $2016-17$ & $2,91,696$ & 1267591 \\
\hline 8. & $2017-18$ & $2,88,889$ & 1556480 \\
\hline 9. & $2018-19$ & $3,09,867$ & 1866347 \\
\hline & Total & $18,66,347$ & \\
\hline & $\begin{array}{c}\text { CAGR (Compound } \\
\text { Annual Growth Rate) }\end{array}$ & $13.73 \%$ & \\
\hline
\end{tabular}

Source: Ministry of Agriculture and Farmer welfare

The Table 2 shows that highest amount of Foreign Direct Investment Inflows in the year of 2018-2019. Every year increased the amount of FDI inflows the Agriculture Sectors. Financial Years 2010-11 To 2018-19.

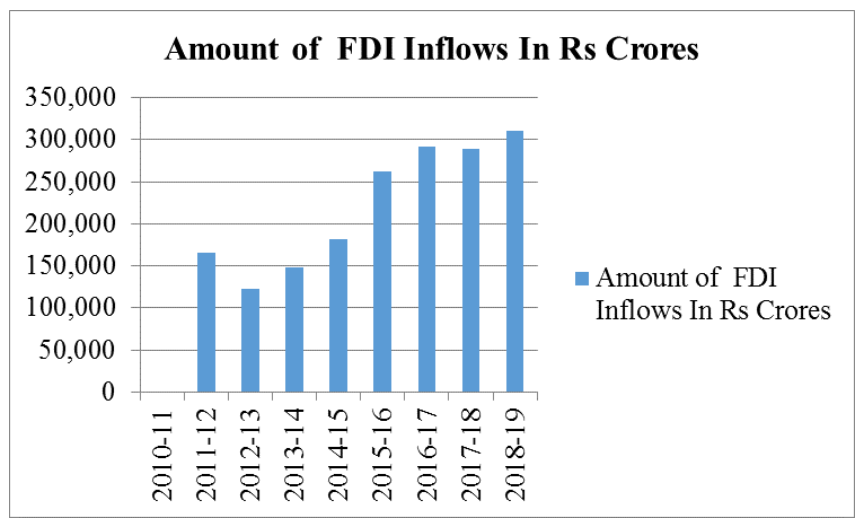

Figure2 : Bar Diagram shows the DPIIT'S - Financial Year-Wise Fdi Equity Inflows in the year 2011-19.

\section{CONCLUSION}

India has a tremendous purchaser and in this manner appealing spot for exchanging of its free outside exchanging approach. Use countries for carrying innovation and stable framework with culture in India, yet control ought to be in our grasp. For rapidly creating economies like India, getting general capacity and overall advancing limits are as critical as access to capital. Extended trade between nations works outside direct adventure. Beside various zones, the governing body of India is consistently moving toward making agriculture a promising hypothesis part for overall players. Monetary Survey demonstrated that the administration was enthused about multiplying ranchers' pay by 2022 , for which it has propelled a few new activities that incorporate exercises from seed to promoting. Credit from institutional sources will supplement all such government activities like Soil Health Card, Input Management, Per Drop More Crop in Pradhan Mantri Krishi Sinchai Yojana (PMKSY), PMFBY, e-Nam, and so on, the review said. Indian ranchers are adjusting to cultivate automation at a quicker.

\section{REFERENCES}

1. Sumit, and Saini Komal, Impact of FDI on Agriculture Sector in India: An Analytical Approach, International journal of basic and applied research www.pragatipublication.com ISSN 2249-3352 (P) 2278-0505 (E) Cosmos Impact Factor-5.960,677 April 2019 Volume 9 Number 4 Indexed in Cosmos UGC Approved Journal.

2. Sonawane Shantaram Tarachand (2017), "A study on FDI in agriculture sector in India" International Journal of Multidisciplinary Education and Research ISSN: 2455-4588; Impact Factor: RJIF 5.12 www.educationjournal.in Volume 2; Issue 3; May 2017; Page No. 29-30

3. Sandeep Kumar, Kavita, "Foreign Direct Investment in Indian Agricultural Sector: Opportunities and Challenges States" October - November, 2014 13 socio - economic voices, www.indiastat.com
4. Singh, K.R. \& Walis, R.K, 2015. Foreign Direct Investment (FDI) \& Agriculture Sector in India. Indian Journal of Research, 4(3), pp6-8

5. www.ibef.org

6. www.economictimes.indiatimes.com 